\title{
Analysis and research of micro learning environment based on mobile network
}

\author{
Liwen Xia \\ Hunan Mass Media Vocationl Technical College, Changsha,Hunan, China
}

Keywords: Learning environment1, learners2, learning conditions3, learning activities4,Mobile network5.

\begin{abstract}
Being increasingly common in our lives, mobile networks have created a mobile, convenient, and individualized environment for microlearning. This transformation has caused change in the format of learning resources made available through micro-courses and MOOC (Massive Open Online Courses) so that they are better suited to mobile networks. This paper analyzes the three elements (learners, learning conditions, and learning activities) of a mobile network-based microlearning environment, and generalizes the internal relationship between these elements, thereby providing references for the design and reform of micro-courses and MOOC.
\end{abstract}

\section{Introduction}

As mobile networks become increasingly common in our lives, smart mobile terminals, the hottest interactive products from 2013 through 2015 on the internet, have enabled the growth of microlearning that combines traditional distance learning with mobile communication technology. They have also made microlearning available anywhere at any time. Having created a convenient, individualized environment for learners, mobile microlearning is gaining ground rapidly in education around the world. Various microteaching models have also emerged, exerting a far-reaching impact on school teaching. Mobile networks have not only facilitated dynamic growth in micro-courses, MOOC, flipped classrooms, and other internet-based "micro" learning models, but they have also brought changes to traditional online learning models, learning platforms, and learning habits. As learning environments become mobile, and teachers, researchers, technicians, and students increasingly rely on mobile networks, people can learn a broad range of things through varying methods at any time, instead of sitting in front of a computer. This transformation of learning environments has caused change in the format of learning resources made available through micro-courses and MOOC (Massive Open Online Courses) so that they are better suited to mobile networks. This paper analyzes the three elements of a

\footnotetext{
a Liwen Xia : 494187438@qq.com ;summerxiaxiaxIw@126.com
} 
mobile network-based microlearning environment, hoping to provide references for the design and reform of micro-courses and MOOC.

\section{Mobile network-based learning environments}

A mobile network-based learning environment is special in that it is designed to be inclusive so as to meet various teaching and learning needs. Given that the study of the mobile network-based learning environment is just beginning, we can categorize elements of the mobile network-based learning environment based on online learning models. "Thus, mobile network-based learning involves learners, learning conditions, and learning activities. The need of learners may affect mobile network-based learning environments. Learners are categorized by basic characteristics and cognitive characteristics as well as their learning preparedness and difficulties. Learning conditions state the combination of factors that ensure continuous learning, including resources, tools, support, and mobile networks. Learning activities represent the combination of factors directly guiding and urging people to learn things through mobile networks, including learning objectives, learning activities, and learning evaluation" $\mathrm{b}$.

\section{Analysis on the elements of mobile network-based learning environments}

We can analyze a mobile network-based learning environment by examining the following three elements: learners, learning conditions, and learning activities. What is the relationship between these elements? What roles does each element play in microlearning? To answer these questions, we need to analyze these elements and generalize the role of each element in microlearning. Relevant analysis is shown as follows:

\subsection{Learners}

Among all items under the learner category, learning needs have the greatest impact on mobile network-based learning. Scholars studied online learning environments. During this study, scholars found that the learners' basic characteristics, cognitive characteristics, learning preparedness, and learning difficulties affected their online learning experiences. Being derived from online learning, mobile network-based learning can better meet the needs created by lifelong learning, inquiry-based learning, and independent learning. See table 1 for analysis of learner categories.

Table 1. Analysis of learner categories.

\begin{tabular}{|c|c|c|c|c|}
\hline $\begin{array}{l}\text { Learner/learn } \\
\text { ing } \\
\text { categories }\end{array}$ & Basic characteristics & $\begin{array}{l}\text { Cognitive } \\
\text { characteristics }\end{array}$ & $\begin{array}{l}\text { Learning } \\
\text { preparedness }\end{array}$ & $\begin{array}{l}\text { Learning } \\
\text { difficulties }\end{array}$ \\
\hline $\begin{array}{l}\text { Lifelong } \\
\text { learning }\end{array}$ & $\begin{array}{l}\text { at least basic } \\
\text { education; no } \\
\text { requirements } \\
\text { regarding age, } \\
\text { gender, and } \\
\text { occupation; } \\
\text { knowledge of }\end{array}$ & $\begin{array}{l}\text { Studies have been } \\
\text { completed; } \\
\text { informal study } \\
\text { required to } \\
\text { continue education } \\
\text { and better suit } \\
\text { employment }\end{array}$ & $\begin{array}{l}\text { Skillfully use of } \\
\text { mobile terminals; } \\
\text { desire to learn } \\
\text { more than what } \\
\text { schools can offer; } \\
\text { desire to dabble in } \\
\text { other fields. }\end{array}$ & $\begin{array}{l}\text { Difficulty with what } \\
\text { to study, how to } \\
\text { study, and with } \\
\text { what occupation to } \\
\text { pursue }\end{array}$ \\
\hline
\end{tabular}

b Information on http://blog.sina.com.cn/s/blog_6d321822010161ya.htmI 


\begin{tabular}{|c|c|c|c|c|}
\hline & mobile terminal use & & & \\
\hline $\begin{array}{l}\text { Inquiry-base } \\
d \text { learning }\end{array}$ & $\begin{array}{l}\text { Some high-school } \\
\text { education or greater, } \\
\text { people who are } \\
\text { under } 15 \text { years old } \\
\text { desire to study } \\
\text { physics, biology, } \\
\text { and terrestrial space }\end{array}$ & $\begin{array}{l}\text { higher education; } \\
\text { strong } \\
\text { observational } \\
\text { and thinking skills; } \\
\text { can develop } \\
\text { knowledge via } \\
\text { inquiry-based } \\
\text { learning. }\end{array}$ & $\begin{array}{l}\text { knowledge } \\
\text { directly related to } \\
\text { fields of study; } \\
\text { have relevant } \\
\text { skills with } \\
\text { cognitive and } \\
\text { meta-cognitive } \\
\text { strategies. }\end{array}$ & $\begin{array}{l}\text { need to solve } \\
\text { problems with } \\
\text { communication or } \\
\text { inquiry, i.e. } \\
\text { confusions due to a } \\
\text { lack of exchange of } \\
\text { information when } \\
\text { pursuing knowledge }\end{array}$ \\
\hline $\begin{array}{l}\text { Independent } \\
\text { learning }\end{array}$ & $\begin{array}{l}\text { willing to study } \\
\text { independently; no } \\
\text { requirements } \\
\text { regarding age, } \\
\text { gender, and } \\
\text { occupation; need } \\
\text { individualized } \\
\text { learning }\end{array}$ & $\begin{array}{l}\text { sharp senses, } \\
\text { stable cognitive } \\
\text { styles, and } \\
\text { preference for } \\
\text { social learning }\end{array}$ & $\begin{array}{l}\text { good learning } \\
\text { habits, strong } \\
\text { willpower; can } \\
\text { freely choose } \\
\text { what, where, and } \\
\text { how to study. }\end{array}$ & $\begin{array}{l}\text { need to solve } \\
\text { personal problems, } \\
\text { i.e. special obstacles } \\
\text { caused by } \\
\text { differences in } \\
\text { gender, age, and } \\
\text { social identity. }\end{array}$ \\
\hline
\end{tabular}

\subsection{Learning conditions}

"Learning resources, learning tools, learning support, and social networks constitute the learning conditions of online learning. These conditions ensure that learning proceeds smoothly, so as to facilitate the realization of learning objectives." c. These four conditions are to be used flexibly by learners. Relevant analyses are as follows:

a) Learning resources: learners are required to be well prepared before their mobile network-based microlearning commences. Relevant organizations should make learning resources available based on the knowledge and experience of learners, information about where and when to study, and learners' attitudes towards customized information. These resources should be made available in multimedia form and uploaded online for potential learners to share. In addition, organizations can deliver learning resources, courseware, and assignments to learners through short messages, multimedia information services, email, or WAP study sites. They can also post information online with regard to learning resources.

b) Learning tools: mobile terminals are required for mobile network-based microlearning. Learners must know how to use learning resources on mobile terminals. Mainstream mobile learning tools today include E-readers, ipads, and smart phones, etc.

c) Learning support: support should be provided to help learners solve difficulties in the mobile network-based microlearning process. Learning platforms should be able to support today' $\mathrm{s}$ mainstream mobile terminal systems; user interfaces for learning resources should be user-friendly in order prevent any obstacles to learning.

d) Social networks: relevant organizations should ensure smooth interactions between learners in their mobile network-based microlearning environment, so that learners can discuss subjects of interests through forums on learning platforms, or exchange their ideas on forums on WAP study sites, or communicate with each other in real time via QQ, WeChat, MSN, and SMS tools, all based on their

c Information on http://blog.sina.com.cn/s/blog_6d321822010161ya.htm/ 
needs and habits.

\subsection{Learning activities}

Learning activities on mobile networks that are based on hypermedia are mobile, virtual, common, popular, individualized, and interactive. Such activities overcome any distance and time limitations, and give learners liberty when making study decisions. Based on the questions of how to set learning objectives for learners in a mobile network-based microlearning environment and how to guide and facilitate learners to participate in various activities (including learning activities and evaluation), we analyze the relationship between the three elements (learners, learning conditions, and learning activities) of the mobile network-based microlearning environment, as shown in figure 1 .

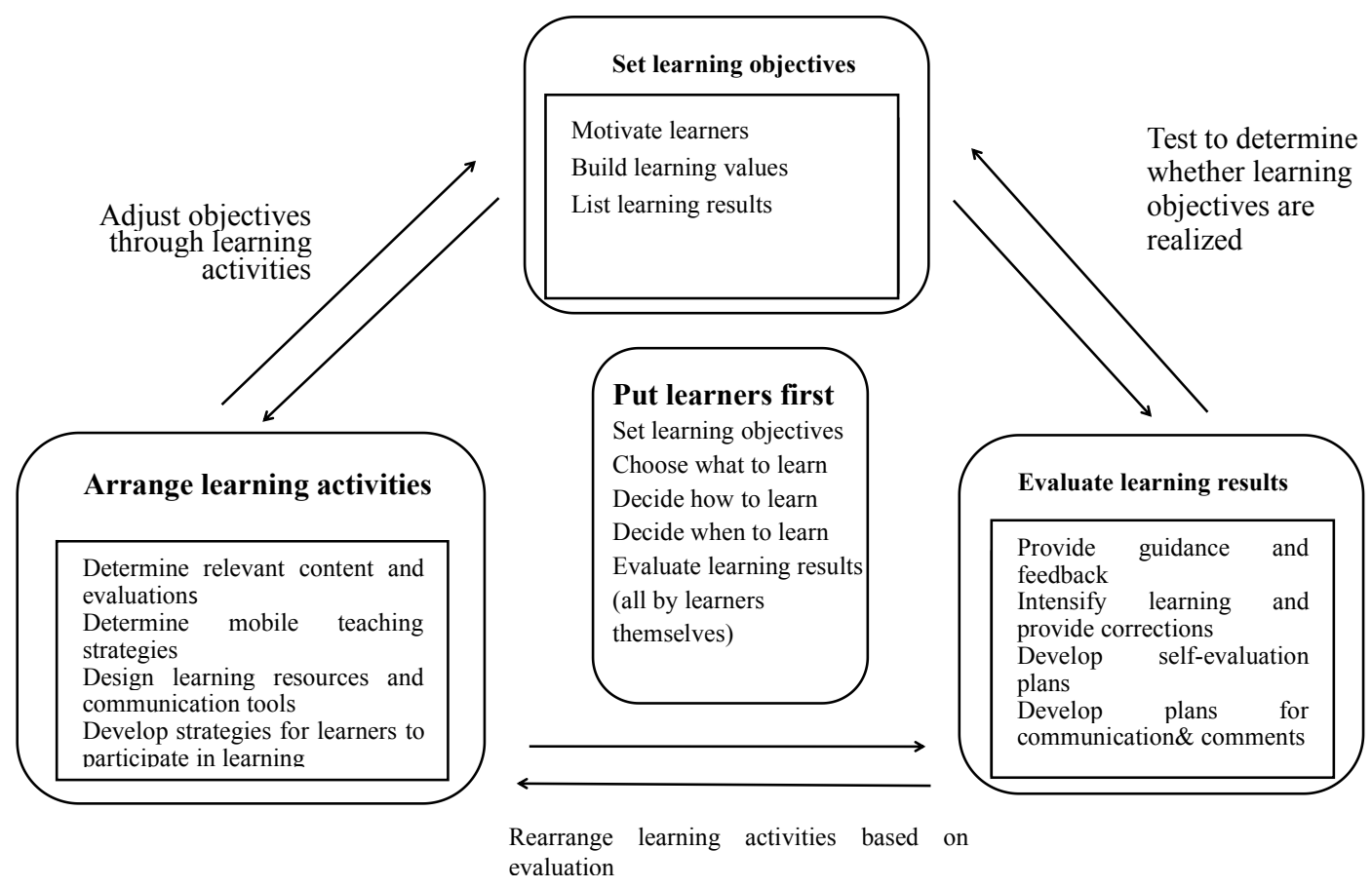

Figure 1. Analysis of learning activities

\subsection{Relationship between learning elements}

According to analyses of the three elements (learners, learning conditions, and learning activities) of the mobile network-based microlearning environment, microlearning environment is mobile, flexible, and efficient. In such an environment, learners can freely determine what, how, and when to study. An Analysis of a mobile network-based microlearning environment that consists of the three elements is shown as figure 2 .

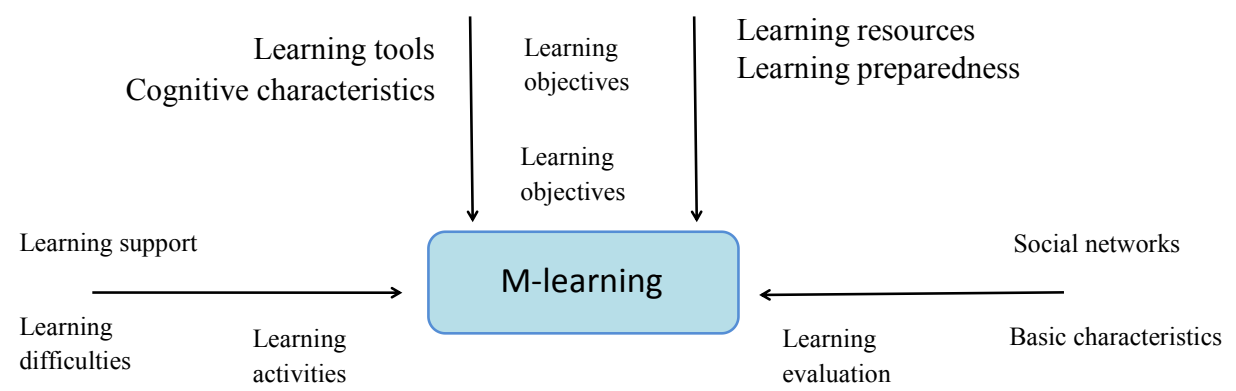

Figure 2. Relationship between the elements of learning environment 


\section{Acknowledgement}

This work is supported by The Twelfth Five-Year Plan on Scientific Education in Hunan Province

(No.XJK015CGD067).

\section{References}

1. Wang Jianhua, Li Jing and Zhang Long,in:Mobile Learning: Theory and Practice, published by Science Press,Beijing,China(2009).

2. Han Lilong,in:Mobile networks. Learning,published by University of Science and Technology of China Press, Hefei,Anhui,China(2011).

3. Yang Fangqi and Yang Gaixue, in:The Content Analysis of Papers on M-learning During Recent 10 Years, published on Journal of Distance Education.Hangzhou,Zhejiang,China(2010),p. 39-45.

4. Information on http://blog.sina.com.cn/s/blog_6d321822010161ya.html

5. Information on http://blog.sina.com.cn/s/blog_46a492570100bqcr.html

6. Information on http://www.360doc.com/content/13/0107/14/3908533_258757745.shtml

7. J. Nielsen, R. Budiu : Mobile Usability, translated by H. Niu, published by Posts \& Telecom, Shenzheng,Guangdong,China(2013).

8. Information on http://www.360doc.com/content/09/0501/23/117171_3339227.shtml

9. Information on http://blog.sina.com.cn/s/blog_74b202620100rOrd.html

10. X. Fu, J. Hu,in: Mobile Design, published by Electronics Industry, Beijing,China(2013). 